Danuta Guzal-Dec, Magdalena Zwolińska-Ligaj

\title{
The Role of Local Action Groups in the Process of Multifunctional Development of a Peripheral Region. A Case Study of the Region of Lublin, Poland
}

\begin{abstract}
The aim of the study is to describe the role of Local Action Groups (LAGs) under the Leader Programme in fostering entrepreneurship and employment in Lubelskie voivodeship. The hypothesis underpinning the study suggested that LAGs operating in rural areas of the Lublin region contribute insufficiently to job creation and provision of entrepreneurial incentives and play insufficient role in enhancing multifunctionality of rural areas. The study was based on document analysis and diagnostic surveys, including an interview questionnaire addressed to representatives of the offices of all 22 LAGs from the studied region. The results revealed that few projects were aimed at the development of non-agricultural functions in rural areas, and demonstrated insufficient involvement of LAGs in the implementation of projects in the bioeconomy sector, which is the key smart specialization of the region. In conclusion the authors assess the overall role of LAGs in creating jobs as marginal and call for paying more attention to the postulates of diversification assumptions resulting from the strategic development documents drafted for the region, including the Regional Innovation Strategy.
\end{abstract}

Keywords: Local Action Groups, Local Development Strategies, rural jobs, multifunctional development.

\section{Introduction}

The Lublin region is located in the border zone, in the Polish Eastern Macroregion. That region features the lowest level of economic development in Poland and one of the lowest in the EU. Polish accession to the EU has enabled external financial support for development. Changes are visible but their dynamics

Danuta Guzal-Dec, PhD, Pope John Paul II State School of Higher Education in Biała Podlaska, danuta_guzal-dec@wp.pl; Magdalena Zwolińska-Ligaj, PhD, Pope John Paul II State School of Higher Education in Biała Podlaska, m.zwolinska-ligaj@dydaktyka.pswbp.pl. 
in rural peripheral areas is still too low. Various types of resources available in rural areas of Lublin Region (especially natural and human ones) can, while maintaining the principles of sustainable development, be involved in the creation of a regional smart specialization such as bioeconomy. This, however, requires initiating sustainable and innovative use of the valuable natural assets and resources in environmental management processes, which in turn, will be possible when local communities are capable of innovating and cooperating in starting business activities (Guzal-Dec, Zwolinska-Ligaj 2015; Guzal-Dec 2016a).

Rural areas of the Lublin region display a number of characteristics typical of peripheral areas. Spatial peripherality is accompanied by economic and sociodemographic peripherality. ${ }^{1}$ In terms of the economic dimension, a particular problem is the monofunctional character of the rural economy, manifested mainly by agricultural production. As a result, development processes are slow. A challenge for the regional development policy is therefore to enhance multifunctionality of rural areas.

It is emphasised in the literature that the market mechanism itself does not adjust the backward regional economic structure, and that positive developmental effects can be achieved by mobilizing the internal potential of the peripheral areas, with the support of public authorities. This support should be directed at stimulating the grass-roots factors, by incentivizing peripheral areas (Leszczewska 2010, p. 223). In the case of these regions, insufficient human and social capital resources do not allow for the initiation of socio-economic development processes to establish a correct trajectory of development and to ensure the appropriate use of economic resources. It is therefore necessary to create conditions to increase the resources of social and human capital in this area (Becla, Czaja 2014, p. 28). The Leader initiative offers such opportunities.

The Leader initiative is based on the economic development model for rural areas called Community-led rural development theory. This model, as presented in the paper "Rural regions in the EU: exploring differences in economic development" identifies "the precondition for promoting and sustaining economic development in rural regions: the existence of community capacity to function effectively on a self-help basis. [...] The community-led rural development theory focuses on the strengthening of the self-help capacity of local actors, which is considered to be a precondition for permitting and sustaining local economic development. Partnerships and adjustments of the institutional structures are seen as the main tools in the process of capacity building" (Terluin 2001). Local Action Groups (LAGs) are units which help implement the Leader initiative

\footnotetext{
1 It is characterized by low population density and population decline (Miszczuk 2013, p. 14).
} 
(Kisiel, Gierwiatowska 2013). They contributed to the emergence and development of the idea of territorial partnership which promotes framework collaboration of public, private and non-governmental sector. The functioning of LAGs under the Leader Programme can be identified as a model example of cooperation, the essence of which is to manage the use of the local potential of human resources (human, social, relational capital). The cooperation is aimed at identifying and mobilizing the use (by definition, in an innovative way) of resources in local development processes. The neo-endogenous development mechanism can be initiated by LAGs starting to use internal resources and external financial support from the EU (Guzal-Dec 2016b). Thus, one of the main tasks faced by the Leader Programme and its LAGs is to strengthen social capital and cultivate proactive behaviours of local communities in order to increase the level of involvement of citizens in the economic development of their area. The Leader approach is seen as a paradigm shift oriented at the social and cultural construct of the territories' institutional capacities (Dargan, Shucksmith 2008; Labianca et al. 2016), whose application has had a significant impact on the governance of predominantly rural European regions.

Apart from the Leader's contribution to the creation of social capital, which is commonly emphasized in the literature, it also generates effects in the area of improving the situation in rural labour markets also under LAGs' tasks. Local Development Strategy (LDS) is a very important element of the Leader Programme. The implementation of LDSs in the period 2007-2013 resulted in job creation mainly as part of the actions such as "Creation and development of micro enterprises”, „Diversification into non-agricultural activities” and as part of the so-called "small projects". Apart from creating jobs, the Leader Programme supports other activities aimed at a broad support of entrepreneurship in rural areas. Beneficiaries receive support for organization of training, research of local markets of goods and services, promotion of local entrepreneurship, starting up production and marketing of goods and services based on local resources, traditions and heritage.

Research to date pointed out positive as well as negative outcomes of the Leader Programme. Studies that have focused on substantial benefits of the Leader pointed to the Leader's role in creating social capital (e.g. Nardone, Sisto, Lopolito 2010; Lafleur, Merrien 2012; Teilmann 2012; Anderson et al. 2014; Guzal-Dec 2014) as well as to a range of non-economic benefits for rural communities, which resulted from the programme implementation (Nembhard 2014; Bosworth et al. 2016). As stressed e.g. by Bosworth et al. (2016), measuring and understanding how "added value" is generated is problematic (Implementation of... 2010; Elliott 2010; Raport... 2012) with purely economic measures showing relatively low indicator 
of job creation ${ }^{2}$ and high costs per job created (Ekosgen 2011; Krievina, Leimane, Melece 2015).

The aim of this study was to describe the role of Local Action Groups under the Leader Programme in fostering entrepreneurship and employment in Lubelskie voivodeship. ${ }^{3}$ The hypothesis underpinning the study suggested that LAGs operating in rural areas of the Lublin region contribute insufficiently to job creation and provision of entrepreneurial incentives and play insufficient role in enhancing multifunctionality of rural areas.

The study focuses on the following research questions:

1. How big is the need to create non-agricultural jobs in the rural areas of the region under study?

2. To what extent do the LAGs contribute to the formation of new entities? In which areas are these entities formed?

3. Are the LAGs an important factor in the development of entrepreneurship and job creation?

\section{Material and methods}

The study involved literature analysis and empirical studies, namely document analysis and diagnostic survey, including an interview questionnaire addressed to all representatives of the offices of $22 \mathrm{LAGs}$ from the studied region. The average size of the area of surveyed LAGs was 1085 square kilometres (standard deviation 482.73) and the average number of residents reached 62,119.50 (standard deviation - 28,091.13). ${ }^{4}$

The survey conducted by telephone interview was addressed to respondents with the most complete knowledge of LAGs functioning, i.e. their presidents or heads of offices. The research material consisted of 20 questionnaires $(0.9 \%$ of all

2 For Latvian example as it was examined in practice, the implementation of the LDS in 20072013 was not balanced: at the planning level, priorities and activities of LDS widely cover entrepreneurship development, though among the implemented projects economy related projects account for only about $18 \%$ of the total approved financing. Most of Leader projects were implemented to facilitate the development of infrastructure related to active recreation and quality leisure time as well as culture and sports (Krievina, Leimane, Melece 2015).

3 The research results were presented in a paper prepared for presentation at the 160th EAAE Seminar 'Rural Jobs and the CAP', Warsaw, Poland, December 1-2, 2016 by D. Guzal-Dec, M. Zwolińska-Ligaj, The impact of Leader Programme on entrepreneurship and employment in the context of multifunctionality of rural areas. A case study of an UE peripheral region (Lublin voivodeship, Poland), http://ageconsearch. umn.edu/bitstream/249763/2/160_EAAE_Seminar_Guzal-Dec_Zwoli\%C5\%84ska-Ligaj_4_12_16_fin.. pdf [accessed:15.01.2017].

4 Data of the Central Statistical Office as at 31st December, 2013. 
the groups operating in the region have been questioned). The questionnaire contained 17 questions, including 8 open questions. Time range of the survey concerned the period 2007-2013. The survey was carried out between June and July 2016. The results are presented in a form of descriptive statistics, tables and graphs. For the purpose of research result presentation the following measures of descriptive statistics were used: arithmetical mean, standard deviation, coefficient of variation, minimal and maximal value, mode, skewness.

The background of empirical research on the characteristics of rural areas of the studied region is based on public statistics data. In particular, the description of transformation of economic and social functions in rural regions was focused on rural communities and rural areas of rural-urban gminas, ${ }^{5}$ in a study period between 2004 and 2014. In this way, the scale of the need to create non-agricultural jobs in the rural areas of the region in question could be determined.

Eight functions of rural areas were studied. These functions were divided in general into agricultural functions and non-agricultural production functions (bio-production: agriculture, forestry, and techno-production: industry and construction) and services. Since it was important for the study to include non-economic functions of rural areas, in addition to features such as tourism and leisure or housing (sleeping function), the study included such non-agricultural service functions as natural landscape and cultural landscape development and protection.

Together with determing the function types in the rural areas of Lublin, a set of twenty diagnostic variables was developed, which variables were arranged in eight groups that measure socio-economic function of rural areas (Annex: Table 5). The variables included in the study were characterized by the ability to discriminate between the functions of the studied units and an acceptable level of correlation with each other. The values of the 20 variables were set for 171 rural gminas and 22 rural-urban and rural gminas of Lubelskie voivodeship for 2004 and 2014. ${ }^{6}$ Next followed standardization of the twenty diagnostic variables and calculation of eight mean averages of the standardized coefficients assigned to each function. Thus, such variables were the basis for the taxonomic grouping of the surveyed units by the k-means method. The existence of five clusters was assumed, and observations were selected so that to maximize the distance of the clusters.

The characteristics of rural areas of Lubelskie voivodeship, including the potential of their economic and social functions and aimed at determining

5 A gmina in which one of the localities has the status of a town.

6 Due to limited access to data, the rural areas of Łaszczów, Modliborzyce and Rejowiec were excluded from the study. For variables 1.2, 1.3, 6.1, 8.1 and 8.2, due to lack of data, data from another year were taken into account. Variables 6.2, 7.2 and 8.3 were based on data from a three-year period (Annex: Table 5). 
the degree of diversification of the local economy, was based on an analysis of k-means clustering. Making use of this method allowed for the isolation of internal relatively homogeneous criteria, in terms of the five clusters (groups) of territorial units - types of gmina functions - adopted for the analysis for 2004 and 2014. This approach made it possible to record trends influencing the local economy in the context of the transformation of their functional structures.

The analysis of variance showed that, with the two separated groupings, all variables were significant in the division of the surveyed areas among individual clusters. In the case of the grouping based on data from 2004, the most important variables included tourism: $\mathrm{F}=98.19$, natural and cultural landscape: $\mathrm{F}=49.24$ and $\mathrm{F}=49.10$, respectively, and industry: $\mathrm{F}=48.88$. In the case of the grouping data for 2014 , the most important variables were tourism: $F=200.00$, industry: $F=54.20$, and services: $\mathrm{F}=45.08$.

\section{Results}

3.1. The advancement of multifunctional development processes in the studied region

The research method of grouping data for 2004 revealed the following types of functional structure: production and residential, agricultural, tourism-forestry, forestry-protective, and mixed. This analysis revealed farming as the dominant type of functional structure of the studied areas, covering $53.16 \%$ of units. The agricultural type included gminas with a dominant role of agriculture in the structure of their economies, and was the best developed compared to other types of functions. These types of gminas were also characterized by a low intensity of non-agricultural activities. Industrial production was the weakest developed sector in comparison to other groups. The level of service function development could be described as average, while tourism functions turned out to be weak. The relatively clear monofunctionality of the economic structure was accompanied by low level of residential function development. Gminas representing the agricultural type do not play an important role in shaping and protecting the natural and cultural landscape. This situation resulted from the characteristics of this group, the level of forestry development - the lowest compared to the others - defined by its small capacity and low efficiency.

The production and residential type, characteristic of $23.16 \%$ of the units, included gminas and rural-urban gmina areas with a highly diversified economy, in which an important role was played by the industrial sector. These units were also strong in the housing sectors. They were characterized by the most developed 
industrial production and a well-developed service sector, with weak development of tourist services. Very well-developed technology, production and service functions were accompanied by an average growth of bio-productive functions, associated with local natural resources. In these units, the forestry function was also present, with an average development of agricultural production function. The smallest contribution from these area units, compared to other types of areas, was to the formation and protection of the natural and cultural landscape.

The third group, representing $17.89 \%$ of the units, was made up of territorial units representing a mixed type, with fairly evenly developed economic functions. The degree of development of agricultural and non-agricultural functions appeared as sustainable. In these units, functions such as agriculture, forestry, industry, and tourism were developed above-average compared with the other groups. Service functions and shaping of the cultural landscape were the most developed in this group, the housing function being the least developed.

Other separated types displayed close connections with the natural wealth of their areas. In comparison with others, the isolated forest-protection type, representing $3.68 \%$ of the total units, was characterized by the highest contribution to the development of the natural landscape and an advanced development of forestry functions. The weakest developed functions, compared to others, were the agricultural production and services functions. The tourism function was relatively well developed, but less than in developed gminas with strong tourism and recreation functions, yet still much higher than for other units. The industry function was also fairly well developed. The forest-protection type, characterized by weak development of the residential function, made a distinct contribution to shaping the cultural landscape.

The last and the least represented type - tourism and forestry - representing $2.11 \%$ of the units, consisted of gminas with a prominent tourist profile, and a muchdiversified economy structure associated with the development of the industrial function. These rural areas feature quite well-developed forestry function and contribute significantly to the formation and protection of the natural and cultural landscape. Agricultural functions are not of vital importance in these areas. Service functions are developed weakly, but the residential functions are quite strong compared to other functions.

Therefore, at the beginning of the decade studied, rural areas of Lubelskie voivodship seem clearly to be dominated by units of agricultural functions. Local economic structures, however, are subject to evolution, so in 2014 the functional types of the territorial units concerned show differences in relation to the data from 2004. 
Mixed type was the most represented type of functional structure, accounting for $34.74 \%$ of the studied units. This type was formed by territorial units with fairly evenly developed economic functions, of which the slightly more advanced were bio-productive functions such as agriculture and forestry; non-agricultural functions, such as industry, tourism and services were less developed. A low level of development was observed in this group in relation to functions of contribution to the development and protection of the natural and cultural landscape and housing. In comparison to 2004, cultural functions and services clearly decreased.

The agricultural type included $31.05 \%$ of units and characterized territorial units with the highest level of development in the agricultural function, as compared to other entities, and played the highest role in the development and protection of cultural landscape. In comparison to 2004, there was a significant development of this function. The development of services appeared to be inadequate. The relatively poorly diversified economic structure is evidenced in the least-developed industrial functions and weak development of tourism and housing. In addition, the agricultural type was characterized by weakly developed functions related to the natural landscape and protection as well as forestry.

The forestry-production type with a share of $17.37 \%$ included territorial units with highly developed (the highest in comparison with other types) industrial and forestry functions and, at the same time, clearly developed protection and natural landscape functions. The weakest developments compared to other types, occurred in the service and agricultural functions. The housing function is quite underdeveloped, and there is only average development of tourism and cultural landscape protection functions. In this group of units with predominantly productive functions, forestry plays a supplementary role. In the grouping based on data from 2004, the dominant production function was accompanied by housing.

In comparison to other separated types, the service and residential type was represented by $15.26 \%$ of territorial units and was characterized by a high degree of development of service, residential and industrial functions. Bio-production forestry and agriculture functions - were very poorly developed, with tourism at an average level. At the same time, these units featured weak development of the shaping and protection of the natural and cultural landscape function. In 2004, there were no units with so highly developed services to provide favourable conditions for housing and jobs in the non-agricultural sector.

The tourism type was represented by three gminas ( $1.58 \%$ of the sum total), with an outstanding tourism profile and, at the same time, compared to other units, their most developed function was that of natural landscape development and protection. These areas offered fairly good conditions for the development of the residential function. Agriculture and forestry were poorly developed. There was a notable 
development of the industrial function. The service functions - market-related and those associated with the formation and protection of the cultural landscape - were at an average level. In relation to the situation in 2004, a noticeable progressive specialization of this type of unit in tourism, and a strengthening of the functions of natural landscape protection and development could be observed.

The functional structure of the surveyed rural areas underwent dynamic changes. The most affected were the units which in 2004 represented local economy structures based on agriculture. Only $39.60 \%$ of them maintained the existing economic structure, with the remaining units subject to transition to diversified and further function structures. There was noticeably a clear revival of the cultural dimension in these units. Almost half (46.53\%) of them transformed into mixed structures, while the remaining ones were changing to production-forestry, services, and residential types (Figure 1).

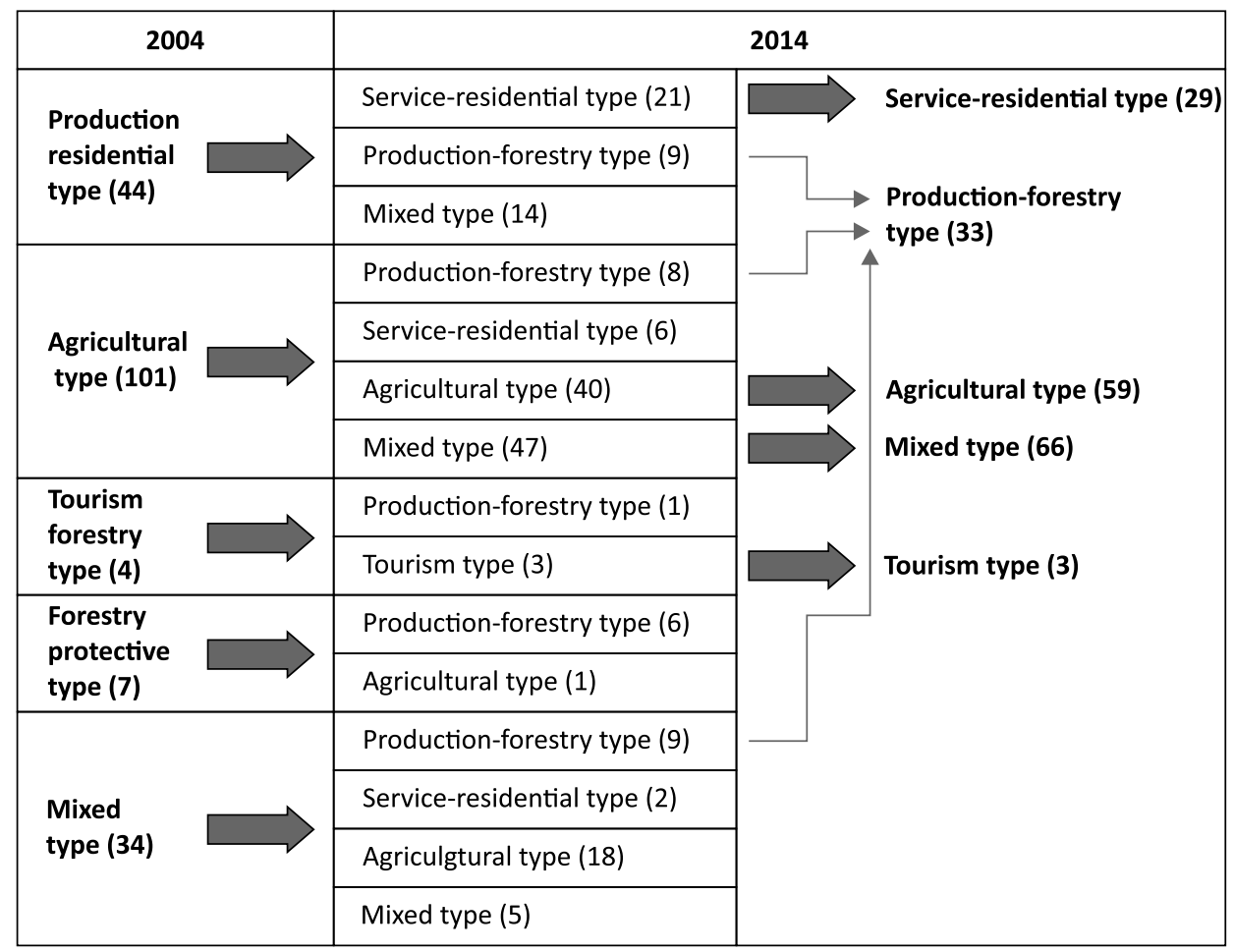

Figure 1. Types of structure functions of rural areas of the Lublin region and their transformations within the period 2004-2014

Source: own report based on the results of the study on functional infrastructure of Lublin's region in rural areas 
Units representing the production-residential type displayed a tendency toward a strong development of the service sectors and almost half of them (47.73\%) transformed into the service and residential type, while the rest changed to the mixed and production-forestry types.

It is characteristic that units of the mixed type tended towards function specialization. For more than half of them (52.94\%) agriculture became the dominant function, while $26.47 \%$ of the units evolved towards the production-forestry type.

Units of the forest-protection type tended to develop the production function (6 of them), or intensify the agricultural function (1), while units of the tourism and forest type were transforming towards specialization and the development of the tourism function ( 3 units), or focused on the development of the forestry production function (1).

Thus, the above described transformation of the functional structures of rural areas, which took place in the period 2004-2014 resulted in progressive diversification of rural areas. It was associated with a clear decrease in the number of units with an outstanding dominance of the agricultural function and development of the non-agricultural economic functions of the studied areas. Particularly noticeable was a clear development of service functions, production functions associated with forestry, and strengthening of tourism in units where it had already been noted as quite strong. These positive processes will require further transformation involving the development of local economic structures with equally advanced economic functionalities, with indications towards further development of the non-agricultural sector and the increasing role of social functions related to the protection and shaping of the natural and cultural landscape.

Expansion of the functional structure of rural areas must take into account the problem of their environmental values. In the case of areas representing significant ecological potential we should take care of more comprehensive use of their functional potential which consists of economic and social functions (ZwolińskaLigaj 2015a, p. 74; Zwolińska-Ligaj 2015b).

3.2. The role of Local Action Groups in economic activation of local interest groups

\subsubsection{LAG formation}

The Leader programme is very popular in the rural areas of the Lublin region. During the period 2007-2013, all rural and urban-rural gminas were affiliated 
to LAGs (Katalog LGD... 2012). As at 31.10.2016, 22 LAGs were functioning in the Lublin region. ${ }^{7}$

As indicated by heads of the LAGs, the interest in forming particular LAGs varied. By far the greatest interest in all tested LAGs was displayed by the local government sector, and it was the local authorities which most often initiated the formation of LAGs. The least interest was shown by farmers and non-agricultural population (mean score below 3). The interest of entrepreneurs in LAGs membership was average. The LAGs that were studied varied to a great extent (the coefficient of variation was approximately 0.4 ) in terms of their involvement in shaping the local community (farmer and non-agricultural populations) (Table 1).

Table 1. Assessment of interest in forming LAGs in particular groups of local population ( $\mathrm{N}=20$ )

\begin{tabular}{lcccc}
\hline \multicolumn{1}{c}{ Local population groups } & \multicolumn{4}{c}{ Measures of descriptive statistics } \\
\cline { 2 - 5 } & $\begin{array}{c}\text { Arithmetic } \\
\text { average }\end{array}$ & $\begin{array}{c}\text { Standard } \\
\text { deviations }\end{array}$ & Dominant & $\begin{array}{c}\text { Variation coefficient } \\
\text { s/x*100\% }\end{array}$ \\
\hline Local government authorities & 4.65 & 0.65 & 5 & 0.13 \\
$\begin{array}{l}\text { Non-government } \\
\text { organizations }\end{array}$ & 4.15 & 0.85 & 4 & 0.21 \\
Entrepreneurs & 3.00 & 1.00 & 4 & 0.25 \\
Non-agricultural population & 2.70 & 1.19 & 3 & 0.40 \\
Farmers & 2.65 & 1.11 & 3 & 0.37 \\
\hline
\end{tabular}

Source: own study based on research; evaluation scale (0-5), where $0=$ lack of interest, and $5=$ very high level of interest.

Among the reasons for low interest of the social and economic sector in participation in LAGs, more than half of the respondents $(55.56 \%)$ indicated lack of knowledge and information on LAG functioning, their operating principles and benefits resulting from LAG actions. For almost one-third of respondents $(27.78 \%)$, the reasons were rooted in overlooking real benefits or conditions for implementation of projects perceived as unattractive. Others pointed to lack of free time of potential candidates, mostly entrepreneurs.

A notable lack of interest in LAGs participation among the local community and enterprises did not cause any particular difficulties in the groups' establishment and development. A vast majority of the surveyed groups (92.86\%) did not observe such

\footnotetext{
7 http://www. ksow.pl [accessed:10.05.2016].
} 
difficulties. A few respondents indicated difficulties resulting from, among other things, the expenditure of resources, the need to shift resources to other activities, retaining appropriate proportions of sectoral approach in appointing Councils for the evaluation of proposals.

\subsubsection{Activity in the projects implementation area}

The LAGs studied featured a high level of variation in activity within the scope of project implementation applications under LDSs (Table 2).

Table 2. The number of accepted applications (that is, passed on to the Marshal's Office) as divided into scope of support from start of enrollment $(N=20)$

\begin{tabular}{llccccc}
\hline \multicolumn{1}{c}{ Scopes/areas of support } & \multicolumn{5}{c}{ Descriptive statistics measures } \\
\cline { 2 - 7 } & $\begin{array}{l}\text { Arithmetic } \\
\text { means }\end{array}$ & $\begin{array}{c}\text { Standard } \\
\text { deviation }\end{array}$ & $\begin{array}{c}\text { Max } \\
\text { value }\end{array}$ & $\begin{array}{c}\text { Min } \\
\text { value }\end{array}$ & $\begin{array}{c}\text { Variation } \\
\text { coefficient } \\
\text { s/x*100\% }\end{array}$ \\
\hline $\begin{array}{l}\text { Diversification } \\
\text { towards non- } \\
\text { agricultural activity }\end{array}$ & $\begin{array}{l}\text { Number } \\
\text { of accepted } \\
\text { applications }\end{array}$ & 10.11 & 4.74 & 22 & 4 & 1.19 \\
$\begin{array}{l}\text { Formation and } \\
\text { development } \\
\text { of micro-enterprises }\end{array}$ & $\begin{array}{l}\text { Number } \\
\text { of accepted } \\
\text { applications }\end{array}$ & 7.63 & 5.47 & 20 & 1 & 1.82 \\
$\begin{array}{l}\text { Renewal and } \\
\text { development } \\
\text { of rural areas }\end{array}$ & $\begin{array}{l}\text { Number } \\
\text { of accepted } \\
\text { applications }\end{array}$ & 30.84 & 21.13 & 84 & 4 & 0.92 \\
Small projects & $\begin{array}{l}\text { Number } \\
\text { of accepted } \\
\text { applications }\end{array}$ & 159.11 & 87.95 & 370 & 48 & 0.61 \\
\hline
\end{tabular}

Source: own study.

As for the number of successful applications, the surveyed LAGs activities were the most diverse in the areas of support related to creation of jobs in rural areas, such as the establishment and development of micro-enterprises, and diversification into non-agricultural activities. In addition, the positive value of the skewness coefficient indicated that most LAGs demonstrated lower than the arithmetic mean activity in applying for funding under those actions. Therefore, generally low level of activity in the implementation of projects aimed at creating new jobs was evident.

Each of the four areas of support had a similar level - about 70\% - of indications of failure by LAGs to implement all anticipated projects, and thus, in each of these areas, only about $30 \%$ of the LAGs managed to accomplish (raise funds for) all 
the planned projects. The least favourable situation was in the area of formation and development of micro-enterprises, where only the smallest number of submitted projects received support and were implemented (Table 3 ).

Table 3. Percentage indication of failure to realize projects by LAGs, per support areas $(\mathrm{N}=20)$

\begin{tabular}{lc}
\hline \multicolumn{1}{c}{ Scopes of support } & $\begin{array}{c}\text { \% indication (LAGs), which had not realized } \\
\text { all assumed projects }\end{array}$ \\
\hline Diversification towards non-agricultural activity & 73.00 \\
Creation and development of micro-enterprises & 77.00 \\
Renewal and development of rural areas & 68.00 \\
Small projects & 73.00 \\
\hline
\end{tabular}

Source: own study.

The respondents indicated that the main reasons for not carrying out all the projects included negative formal ratings of applications at various stages $(42.86 \%)$, and the withdrawal of applicants (39.29\%), mostly due to complicated formalities and prolonged final evaluation of applications. Other causes were associated with frequent regulatory changes in the Marshal's Office, hindering the application process, and failure by the applicants to start carrying out a project because they regarded the conditions of a project's implementation as unfavourable.

The implementation of projects aimed at creating jobs was, according to the vast majority of respondents, associated with a variety of difficulties. Only 8.69\% of respondents did not see any difficulties. The main issues were the requirements for substantial funds for the establishment of such projects (indicated by $28.57 \%$ of respondents). The requirements relating to the minimum number of jobs created and the need to maintain them $(23.81 \%)$ were the conditions generally perceived as unfavourable (14.29\%). Added to these was the lack of those willing to participate, or applicants' resignations (9.52\%), and bureaucracy (4.76\%). The results of simultaneous studies indicate that in comparison to the previous outlook, the 2014-2020 applicants from outside the local government sector demonstrate a much higher level of activity.

\subsubsection{Role of LAGs in local development}

It should be noted that the LAGs' impact on local development made by the groups' representatives achieved the highest rates (the total of $90 \%$ indications for the greatest impact, with an average rating of 4.4 on a $0-5$ scale) in the development 
of new initiatives in the local community. They also create new forms of cooperation in the local community ( $80 \%$ indications for the greatest impact, with an average rating of 4.0). An average level (35\% indications of high impact, and $45 \%$ of an average impact) of 3.2 was ascribed to the LAGs' impact on the formation of new businesses in rural communities. It is important to note that none of the LAGs turned out as the one which failed to influence the process of local development in the areas analysed (Figure 2).

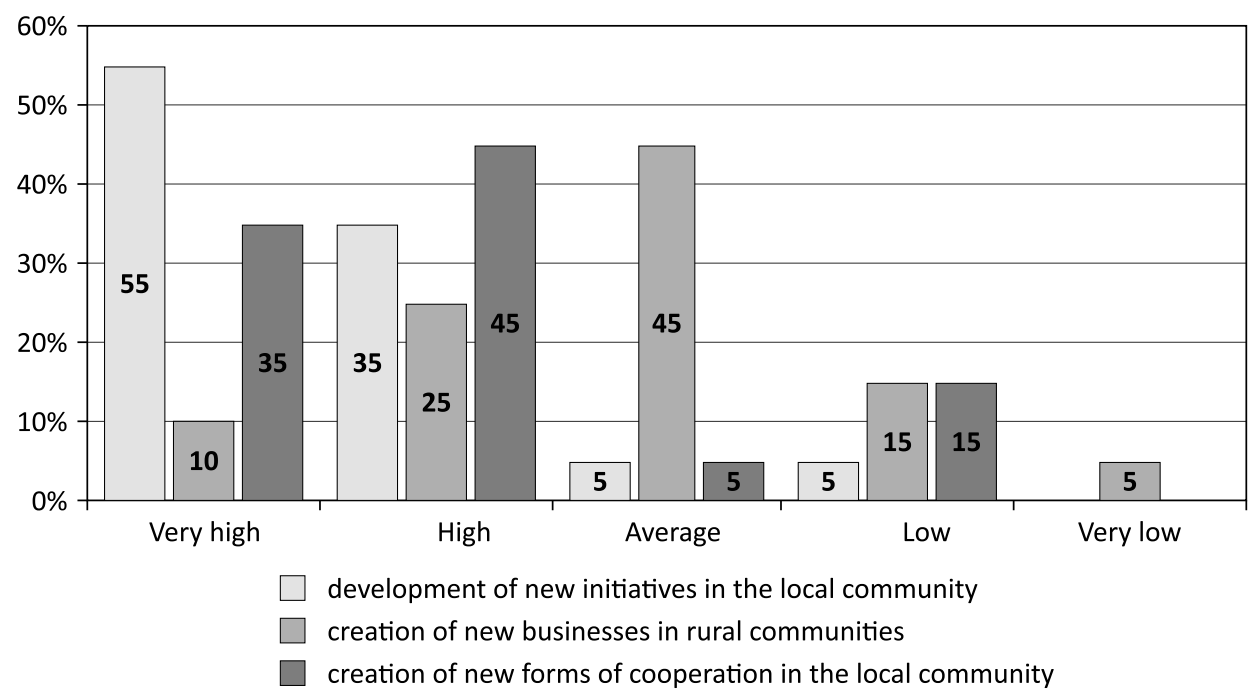

Figure 2. Assessment of LAGs' influence on local development in terms of select areas of influence $(\mathrm{N}=20)$

Source: own study.

The research results regarding the assessment of LAGs' impact on local development in Lubelskie voivodship bring to a conclusion that the LAGs' overall role in creating jobs should be assessed as average, but that they create an important platform focused on stimulating local social activity.

Since the establishment of the surveyed LAGs, 13 jobs (statistical deviation 8.41) were created on average in each of the groups. The number of jobs created in each group ranged from 2 to 34 . Considering the impact of LAGs on the creation of jobs, it should be noted that, most frequently, the studied LAGs in the Lublin region show a great deal of interest in social projects aimed at creating new jobs (average of 3.65 on a scale of $0-5$ ) (Figure 3 ).

Results from Lubelskie voivodeship are consistent with the results of a survey conducted on a sample of 120 LAGs in Poland concerning the impact of LAGs 
operation on diversification of economic activities in rural areas in Poland presented in the report "Evaluation of the RDP 2007-2013 on the quality of life in rural areas, taking into account the Leader approach". In a nationwide study (national) members of the LAGs usually indicated the average impact of LAGs operation in 2007-2013 to increase job opportunities outside agriculture (Figure 4).

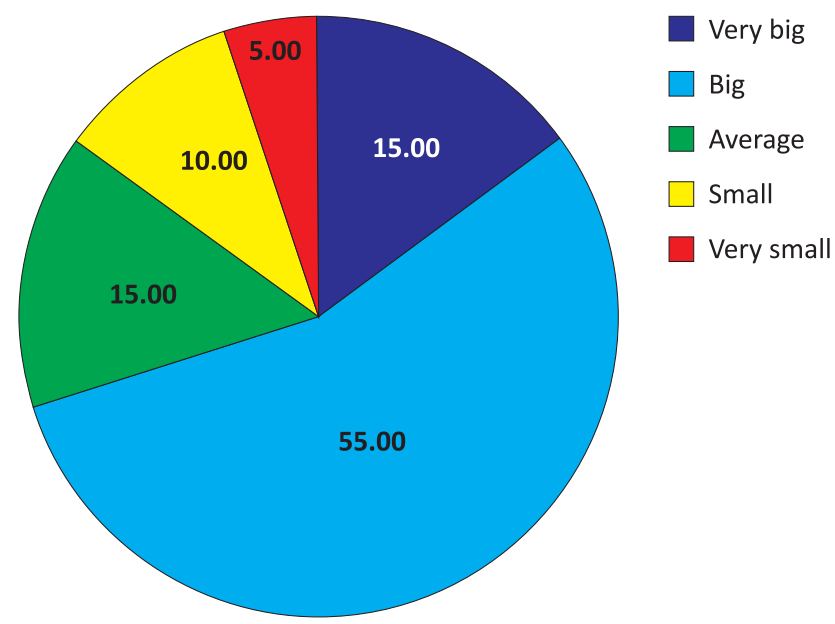

Figure 3. Evaluation of social interest in projects aimed at creating new jobs $(\mathrm{N}=20$; in \%)

Source: own study.

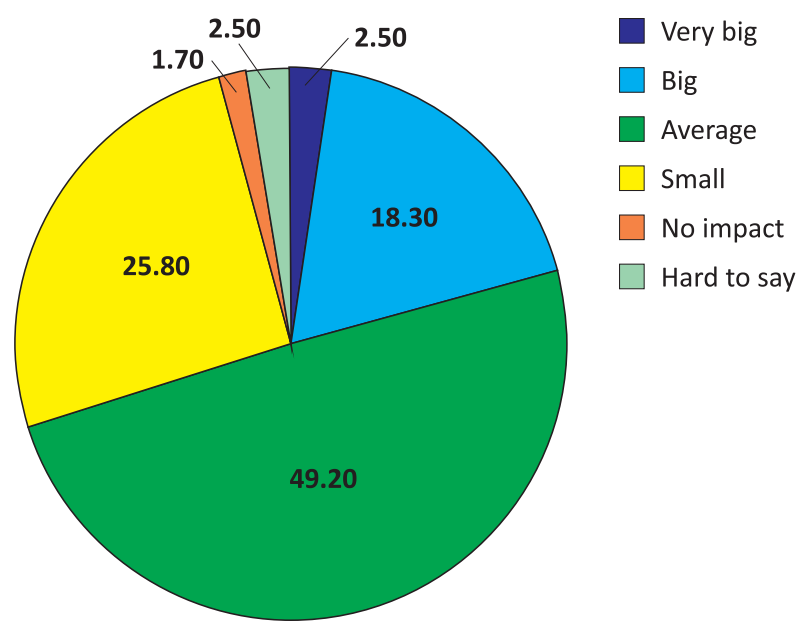

Figure 4. The impact of LAGs' activities in 2007-2013 to increase the possibility of finding non-agricultural jobs in Poland ( $N=120$; in \%)

Source: Raport końcowy. Ocena wpływu..., 2016, p. 82. 
Under the measure "Diversification into non-agricultural activities", as in the case of the total number of LAGs operating in Poland (Raport... 2012, pp. 16-18), jobs were created mainly in the following types of operations: services for agricultural farms or forestry, tourism and sports-related services, recreation and leisure, and services for the population and construction and installation services (Table 4). The structure of the surveyed micro-enterprises, formed by LAGs, is similar, but does not accurately reflect the structure of activity in this area for the total number of LAGs in Poland (Raport... 2012, 16-18). In the Lubelskie voivodship, most microenterprises were formed in tourist services and services for population; in the case of the general LAGs structure in Poland this order is reversed.

Table 4. Structure/Completed contracts under the measure "Diversification into non-agricultural activities" and "Creation and development of micro-enterprises" $(\mathrm{N}=20)$

\begin{tabular}{|c|c|c|}
\hline \multirow[t]{2}{*}{ Types of economic activity } & \multicolumn{2}{|c|}{ Types of measures } \\
\hline & $\begin{array}{l}\text { Diversification into non- } \\
\text { agricultural activities }\end{array}$ & $\begin{array}{l}\text { Creation and development } \\
\text { of micro-enterprises }\end{array}$ \\
\hline Services for farms or forestry & 47.56 & 5.43 \\
\hline Services to the public & 15.24 & 21.74 \\
\hline Wholesale and retail & 1.22 & 11.96 \\
\hline Crafts or handicrafts & - & 6.52 \\
\hline $\begin{array}{l}\text { Construction and construction and } \\
\text { installation services }\end{array}$ & 3.05 & 6.52 \\
\hline $\begin{array}{l}\text { Tourism services, and services related } \\
\text { to sports, recreation and leisure }\end{array}$ & 29.88 & 40.22 \\
\hline Transportation services & - & - \\
\hline Municipal services & 0.61 & - \\
\hline $\begin{array}{l}\text { Processing of agricultural products } \\
\text { and edible forest products }\end{array}$ & 1.22 & 1.09 \\
\hline Warehousing and storage of goods & 2.11 & 3.26 \\
\hline $\begin{array}{l}\text { Production of energy products from } \\
\text { biomass }\end{array}$ & - & 1.09 \\
\hline $\begin{array}{l}\text { Accounting, consulting and IT } \\
\text { services }\end{array}$ & - & 2.17 \\
\hline
\end{tabular}

Source: own study.

Thus, it has been shown how small is the scale of projects aimed at the development of non-agricultural functions of rural areas. Involvement of LAGs 
in bio-economy sector projects, which are key to smart region specialization, was assessed as insufficient. The jobs under the measure "diversification into nonagricultural activities" were created mainly in services for farms and forestry. The surveyed LAGs facilitated diversification of economies mainly in the development of the tourism sector. However, the involvement of LAGs in the diversification of economic activities through the development of sectors outside agriculture, constituting the core of the concept of the bio-economy, was insufficient. Especially problematic is the shortage of activities in areas such as the processing of agricultural products and edible forest products and the production of energy products from biomass. These sectors also showed small-scale formation of micro-enterprises.

The representatives of Lubelskie voivodeship LAGs were actively involved in helping project originators in the implementation of projects, mainly in the form of advisory support regarding the conditions of possible support within the LAGs framework, help in establishment, and ongoing consultations. This activity was usually of an individual character and was organized in the event of needs reported by the applicants. Support for project originators was declared by $75 \%$ of the surveyed group representatives (Figure 5).

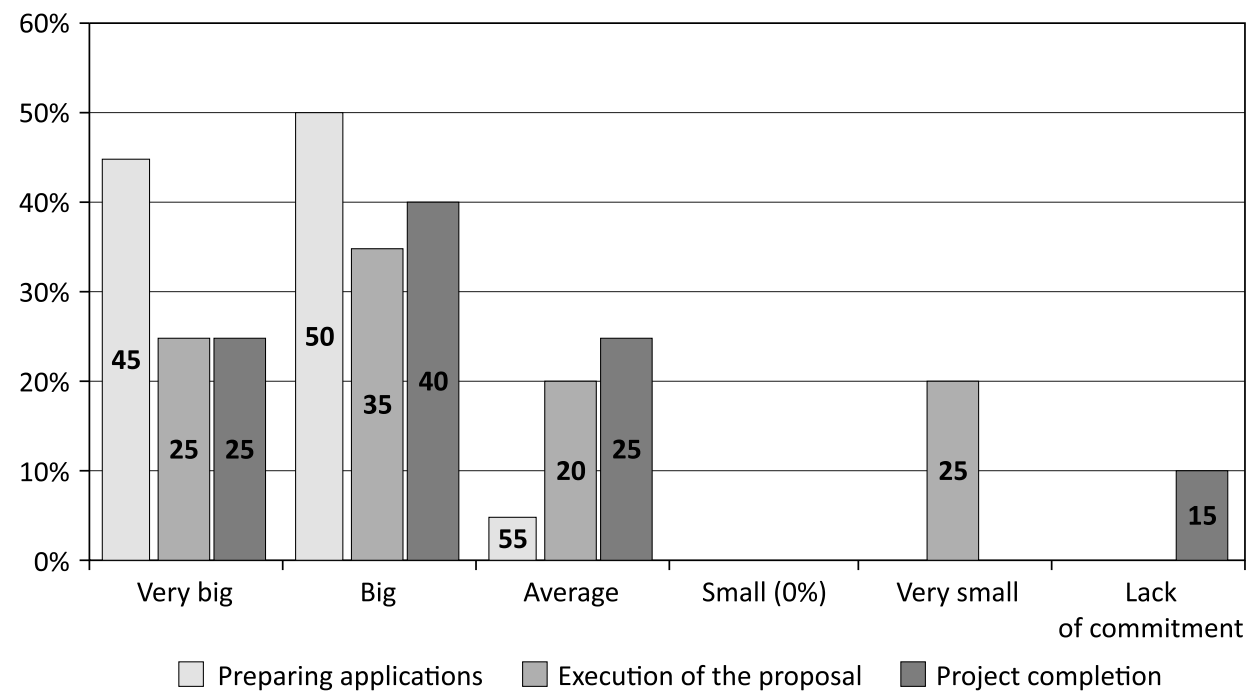

Figure 5. Evaluation of the involvement of LAGs offices in various stages of project implementation $(\mathrm{N}=20)$

Source: own study.

The involvement of LAG offices in helping applicants carry out their projects was revealed mainly at the stage of preparing applications - the respondents have 
identified it as large (average rating of 4.40 on a rating scale of $0-5$, where 0 means no activity and 5 - a very strong commitment). A slightly smaller involvement was shown in other phases of project implementation, namely proposal acceptance and project completion, which was defined as above average (3.45 and 3.6, respectively). Similar conclusions, indicating the fundamental role of LAGs in aiding beneficiaries at the application stage and lesser commitment to the next stages of the project are presented in the report "Raport... 2012" (p. 39).

The small scale of applying the innovation criterion in evaluating projects for support under LAGs is worrying. This criterion, potentially important in stimulating innovation in local economies, was applied only in the case of $35 \%$ of the groups.

Therefore, the results obtained in terms of LAGs' impact on local development are consistent with the conclusions of the assessment report on the functioning of local action groups implementing local development strategies within the Rural Development Programme for 2007-2013 (Raport... 2012, p. 7). The conclusions indicate, among other things, that the concept of innovation is the weakest part of the Leader Programme, as it is not clearly defined and it is understood differently by individual participants. Moreover, bureaucratic procedures may lead to rejection of innovative projects at the level of evaluation carried out by the Marshal's Office.

The role of LAGs in local development should also be considered from the perspective of their impact on the development of local entrepreneurship in the dissemination of knowledge and skills in the area. In the case of more than half of the LAGs (60\%), operations included organization of courses/training aimed at the development of local entrepreneurship. Lack of providing such services by a part of the groups studied, was explained by the operation, in the immediate vicinity, of numerous institutions that specialize in supporting enterprise development (2 groups) or by lack of such needs on the part of group members (2 groups). The remaining ones (4), which did not organize training or courses, stressed their intensive activity in organizing training aimed at registering applications and at developing economic activities.

\section{Conclusions}

1. Analyses of the economic functions of rural areas in Lubelskie voivodeship performed in 2004 demonstrated the dominance of the agricultural function. During the period under study (2004-2014), the rural region under consideration revealed an ongoing process of development of non-agricultural sectors of the economy and an increased number of territorial units with a diversified functional structure, able to provide jobs in rural areas. These positive processes will require further transformation involving the development of local economic 
structures, and finding a balance between agricultural and non-agricultural functions, and equally developed non-agricultural economic functions. There is also a need to develop social functions related to the protection and shaping of the natural and cultural landscape. Such an approach, in line with the principles of multi-functional and sustainable development, could become an important factor in the development of rural labour markets.

2. The study of LAGs' operations in Lubelskie voivodship in the period between 2007-2013 and their impact on the development of entrepreneurship and job creation in rural areas revealed that:

- The LAGs contribution to the formation of new entities was small. Most of the studied LAGs demonstrated a lower than average level of activity in applying for funds aimed at the creation of new jobs. One of the issues raised, which was related to the creation of jobs in the Leader Programme (resulting from the complexity of procedures), was the withdrawal of the applicants. Another reported problem was the difficulty to ensure the sustainability of jobs created. These difficulties were mentioned in the context of the difficult conditions for business development created by national legislation. Created jobs insufficiently diversified structures of local economies and the most common ones were created without taking into account the criterion of innovativeness of planned projects. The scale of projects aimed at the development of non-agricultural functions of rural areas was particularly small. LAGs' projects were developed mostly in sectors such as services for farms or forestry, services to the public, tourism services, and services related to sports, recreation and leisure. Otherwise, the projects were too rarely focused on the development of various areas of production. It should also be noted that involvement of LAGs in the implementation of projects in the area of the bioeconomy, which is the key smart specialization of the region, was insufficient.

- LAG's overall role in creating jobs was insignificant, but this could be due to the generally difficult conditions for the development of entrepreneurship in rural areas. LAGs' activity in supporting rural entrepreneurship should be assessed positively. LAGs provide critical support for applicants at each stage of projects aimed at creating new jobs (but mainly in the preparatory phase). LAGs also play a basic role in the dissemination of knowledge and skills in the area of entrepreneurship. It is desirable to intensify advisory support from LAGs at every stage of the projects and their greater involvement in entrepreneurial training, and procedures for obtaining financial resources.

- The hypothesis used for the study was verified positively: LAGs operating in rural areas of the Lublin region create insufficient number of jobs and entrepreneurial incentives and play insufficient role in stimulating multifunctionality of rural areas. 
3. The results of the studies indicate that in comparison to the previous outlook for 2014-2020 perspective, applicants from outside the local government sector are considerably more active. Solutions proposed for the 2014-2020 perspective prefer to a greater extent non-agricultural entrepreneurship and diversification of sources of income for the rural population, including the development of processing and, more broadly - non-agricultural sectors related to the bio-economy. This suggests that in the current term (2014-2020) LAGs will become a stronger factor in stimulating positive changes in local economies.

4. Taking into account the results of the research it should be noted that the Programme Managing Authority should introduce a system of preferences for compliance between those directions of non-agricultural activities which are planned to be supported and the directions of economic activity provided for rural areas development which are identified in the strategic documents of regional development, including the Regional Innovation Strategies.

\section{Bibliography}

Anderson C.R., Brushett L., Gray T.W., Renting H. (2014). Working together to build cooperative food systems. Journal of Agriculture, Food Systems, and Community Development, 4 (3), 3-9.

Becla A., Czaja S. (2014). Rola kapitału ludzkiego i społecznego w określeniu ścieżki rozwoju ekonomicznego w regionach problemowych. Optimum: Studia Ekonomiczne, 2 (68), 16-28.

Bosworth G., Annibal I., Carroll T., Price L., Sellick J., Shepherd J. (2016). Empowering local action through neo-endogenous development: The case of LEADER in England. Sociologia Ruralis, 56 (3), 427-449.

Dargan L., Shucksmith M. (2008). LEADER and innovation. Sociologia Ruralis, 48 (3), 271-294.

Ekosgen (2011). National impact assessment of leader report for DEFRA.

Elliott J. (2010). DEFRA: Rural development programme for England 2007-2013: mid-term evaluation, (1), Hyder and ADAS.

Guzal-Dec D. (2014). Partnerstwa międzysektorowe - lokalne grupy działania jako instrument wykorzystania zasobów lokalnych w procesie zrównoważonego rozwoju obszarów przyrodniczo cennych województwa lubelskiego. Roczniki Naukowe SERiA, 16 (4), 109-114.

Guzal-Dec D. (2016a). Leader initiative as a factor of social innovations in the development of the environmentally valuable areas of Lublin Region (Poland). In: K. György (ed.). XV Nemzetközi Tudományos Napok "Innovációs kihívások és lehetösé 20142020 között: a tudományos napok publikaćiói” (pp. 605-613). Gyöngyös: Károly Róbert Föiskola. 
Guzal-Dec D. (2016b). Local Action Groups in the development of rural areas in Lubelskie voivodeship (Poland). Proceedings of the 2016 International Conference "Economic Science for Rural Development", (42), Jelgava, LLU ESAF, 21-22 April, 65-71.

Guzal-Dec D., Zwolińska-Ligaj M. (2015). Propozycja modelu instytucjonalno-organizacyjnego wsparcia wykorzystania zasobów i walorów środowiska przyrodniczego w procesach stymulowania rozwoju obszarów przyrodniczo cennych. In: D. Guzal-Dec, A. Siedlecka, M. Zwolińska-Ligaj, Ekologiczne uwarunkowania i czynniki rozwoju funkcji gospodarczych na obszarach przyrodniczo cennych województwa lubelskiego (pp. 267-273). Biała Podlaska: Wydawnictwo PSW JPII.

Guzal-Dec D., Zwolińska-Ligaj M. (2016). The impact of Leader Programme on entrepreneurship and employment in the context of multifunctionality of rural areas. A case study of UE peripheral region (Lublin voivodeship, Poland). http://ageconsearch.umn.edu/bitstream/249763/2/160_EAAE_Seminar_Guzal-Dec_Zwoli\%C5\%84ska-Ligaj_4_12_16_fin.. pdf [accessed: 15.01.2017].

http://www.ksow.pl [accessed: 10.05.2016].

Implemenation of the Leader approach for rural development, Special Report 5 (2010), European Court of Auditors.

Katalog LGD - lokalne grupy działania i ich działalność na obszarach wiejskich (2012). Warszawa: Ministerstwo Rolnictwa i Rozwoju Wsi.

Kisiel R., Gierwiatowska M. (2013). Functioning of the Polish LAG in the Context of the Leader Initiative. Acta Scientiarum Polonorum. Oeconomia, 12 (3), 39-50.

Kovách I. (2000). LEADER, a new social order, and the Central- and East-European Countries. Sociologia Ruralis, 40 (2), 181-189.

Krievina A., Leimane I., Melece L. (2015). Role of Local Action Groups in addressing regional development and social problems in Latvia. Research for rural development, 2, 146-153.

Labianca M., De Rubertis S., Belligiano A., Salento A. (2016). Innovation in rural development in Puglia, Italy: Critical issues and potentialities starting from empirical evidence. Studies in Agricultural Economics, 118, 38-46.

Lafleur M., Merrien A.M. (2012). The Socio-Economic Impact of Cooperatives and Mutual. IRECUS.

Leszczewska K. (2010). Aktywność ekonomiczna regionów peryferyjnych. Nierówności społeczne a wzrost gospodarczy. Spójność społeczno-ekonomiczna a modernizacja gospodarki, 17, 215-225.

Miszczuk A. (2013). Uwarunkowania peryferyjności regionu przygranicznego. Lublin: Norbertinum.

Nardone G., Sisto R., Lopolito A. (2010). Social capital in the LEADER initiative: A methodological approach. Journal of Rural Studies, 26 (1), 63-72.

Nembhard J.G. (2014). Benefits and impacts of cooperatives. Grassroots Economic Organizing (GEO) Newsletter, 2, Theme 18.

Raport końcowy. Ocena funkcjonowania lokalnych grup działania realizujących lokalną strategię rozwoju w ramach PROW 2007-2013 (2012), http://ksow.pl/fileadmin/ 
user_upload/ksow.pl/pliki/ANALIZY_ekspertyzy/LGD_raport_poprawiony_ost_ bis_10_09_2012.pdf [accessed: 20.06.2016].

Raport końcowy. Ocena wpływu PROW 2007-2013 na jakość życia na obszarach wiejskich z uwzględnieniem podejścia LEADER (2016). http://www.minrol.gov.pl/Wsparcierolnictwa/Program-Rozwoju-Obszarow-Wiejskich-2007-2013/Dokumenty-analizyraporty/Analizy-i-raporty [accessed: 20.06.2016].

Teilmann K. (2012). Measuring social capital accumulation in rural development. Journal of Rural Studies, 28, 458-465.

Terluin I.J. (2001). Rural Regions in the EU: Exploring Differences in Economic Development. Groningen: Rijksuniversiteit Groningen.

Zwolińska-Ligaj M. (2015a). Functional classification of rural areas in the Lubelskie Voivodship including their natural values. Barometr Regionalny, 13 (1), 67-75.

Zwolińska-Ligaj M. (2015b). Integracja funkcji gospodarczych i środowiskowych na obszarach przyrodniczo cennych województwa lubelskiego. Perspektywa przedsiębiorstw. Biała Podlaska: Wydawnictwo PSW w Białej Podlaskiej.

\section{Annex}

Table 5. Indicators used in the study according to the functions of rural areas

\begin{tabular}{|c|c|}
\hline $\begin{array}{l}\text { Number } \\
\text { and name } \\
\text { of the functions }\end{array}$ & Index number and name \\
\hline \multirow[t]{3}{*}{ 1. Agriculture } & 1.1. The percentage of agricultural land in the municipal area in total \\
\hline & $\begin{array}{l}\text { 1.2. The percentage of households generating income from agriculture in total } \\
\text { households }(2002,2010)\end{array}$ \\
\hline & $\begin{array}{l}\text { 1.3. The average area of individual farm engaged in agricultural activity over } 1 \text { ha } \\
\text { of agricultural land }(2002,2010)\end{array}$ \\
\hline \multirow[t]{2}{*}{ 2. Forestry } & 2.1. The percentage of the total area of forests in gmina \\
\hline & 2.2. Acquisition of merchantable timber in $\mathrm{m}^{3} / 100$ ha of forest areas \\
\hline \multirow[t]{2}{*}{ 3. Industry } & $\begin{array}{l}\text { 3.1. Proportion of people employed in industry and construction in the total } \\
\text { employment }\end{array}$ \\
\hline & $\begin{array}{l}\text { 3.2. The number of entities and construction industry sections per } \\
1000 \text { inhabitants in the productive age }\end{array}$ \\
\hline \multirow[t]{2}{*}{ 4. Services } & $\begin{array}{l}\text { 4.1. The number of entities and service sections of the private sector } \\
\text { (excluding sections } \mathrm{I}^{*} \text { and } \mathrm{R}^{* *} \text { of the Regon register) per } 1000 \text { inhabitants } \\
\text { in the productive age }\end{array}$ \\
\hline & $\begin{array}{l}\text { 4.2. Proportion of entities in the service section in the total number of entities } \\
\text { registered in the Regon register }\end{array}$ \\
\hline
\end{tabular}




\begin{tabular}{|c|c|}
\hline \multirow[t]{3}{*}{ 5. Tourism } & 5.1. Total tourism accommodation per $1 \mathrm{~km}^{2}$ in gminas \\
\hline & $\begin{array}{l}\text { 5.2. The number of overnight stays in tourist accommodation per 1,000 gmina } \\
\text { residents in productive age }\end{array}$ \\
\hline & $\begin{array}{l}\text { 5.3. The number of entities representing tourism section (Section } \mathrm{I}^{*} \text { and } \mathrm{R} \\
* * \text { of the Regon register) per } 1000 \text { inhabitants in the productive age }\end{array}$ \\
\hline \multirow[t]{3}{*}{ 6. Housing } & 6.1. Number of daily commuters; incoming vs. outgoing workers (2006) \\
\hline & $\begin{array}{l}\text { 6.2. Migration attractiveness factor (the ratio of net migration to the market) } \\
(2004-2006,2012-2014)\end{array}$ \\
\hline & 6.3. Population density $/ 1 \mathrm{~km}^{2}$ \\
\hline \multirow{2}{*}{$\begin{array}{l}\text { 7. Shaping and } \\
\text { protection } \\
\text { of the natural } \\
\text { landscape }\end{array}$} & $\begin{array}{l}\text { 7.1. The share of protected areas (national, landscape parks and nature } \\
\text { reserves) in the total area of a gmina }\end{array}$ \\
\hline & $\begin{array}{l}\text { 7.2. Expenditures of gmina for protecting the natural environment per } \\
1 \text { inhabitant (for the protection of ambient air and climate, wastewater } \\
\text { management and water conservation, waste management) (2004-2006, } \\
2012-2014)\end{array}$ \\
\hline \multirow{3}{*}{$\begin{array}{l}\text { 8. Shaping and } \\
\text { protection } \\
\text { of the cultural } \\
\text { landscape }\end{array}$} & $\begin{array}{l}\text { 8.1. The number of participants in cultural events organized by a gmina per } \\
1000 \text { inhabitants }(2007,2014)\end{array}$ \\
\hline & $\begin{array}{l}\text { 8.2. The number of members of the artistic groups in a gmina per } \\
1000 \text { inhabitants (2007) }\end{array}$ \\
\hline & $\begin{array}{l}\text { 8.3. Expenses of local authorities for culture and protection of national heritage } \\
\text { per } 1 \text { inhabitant }(2004-2006,2012-2014)\end{array}$ \\
\hline
\end{tabular}

* Activities related to accommodation and catering services, ${ }^{* *}$ Activities related to culture, entertainment and recreation.

Source: own study.

\section{Rola lokalnych grup działania w wielofunkcyjnym rozwoju regionu peryferyjnego. Studium przypadku regionu lubelskiego (Polska)}

Streszczenie: Celem opracowania jest ukazanie roli lokalnych grup działania (LGD) w ramach programu Leader w kreowaniu przedsiębiorczości i miejsc pracy w województwie lubelskim. Osiągnięciu celu służyło sformułowanie następujących hipotez badawczych: LGD funkcjonujące na obszarach wiejskich województwa lubelskiego w niedostatecznym stopniu przyczyniają się do tworzenia miejsc pracy oraz kreowania przedsiębiorczości i odgrywają niewystarczającą rolę w stymulowaniu wielofunkcyjności obszarów wiejskich. W opracowaniu wykorzystano metodę analizy dokumentów oraz sondażu diagnostycznego z wykorzystaniem kwestionariusza wywiadu skierowanego do przedstawicieli wszystkich 22 LGD funkcjonujących w badanym regionie. Wyniki ujawniły niewielką skalę projektów ukierunkowanych na rozwój pozarolniczych funkcji obszarów wiejskich i niewystarczające 
zaangażowanie w realizację projektów w sektorze bioekonomii, który jest kluczową inteligentną specjalizacją regionu. Rolę badanych LGD w kontekście tworzenia miejsc pracy należy ocenić jako nieznaczną - sytuacja ta wymaga przyjęcia kierunków dywersyfikacji wynikających ze strategicznych dokumentów rozwoju regionu, w tym szczególnie z Regionalnej Strategii Innowacji.

Słowa kluczowe: lokalne grupy działania, lokalne strategie rozwoju, wiejskie miejsca pracy, rozwój wielofunkcyjny. 